\title{
Ruptura nekoronárního Valsalvova sinu s komunikací do pravé síně jako prričina progrese námahové dušnosti
}

\author{
Alexandr Schee1, Tomáš Marek1, Petr Syrovátka', Michael Želízko', Vladimír Karmazín', Miloš Kubánek', Pavel \\ Šulc ${ }^{1}$, Jan Pirk'2, Josef Kautzner ${ }^{1}$ \\ ' Klinika kardiologie, Institut klinické a experimentální medicíny, \\ 2 Klinika kardiovaskulární chirurgie, Institut klinické a experimentální mediciny, Praha, Česká republika
}

Adresa: MUDr. Alexandr Schee, Klinika kardiologie, IKEM, Vídeňská 1958/9, 14021 Praha 4, Česká republika, e-mail: alsc@medicon.cz

Cílem tohoto sdělení je prezentace obrazové dokumentace $\mathrm{z}$ diagnostického procesu u 56letého pacienta s mnohaletou anamnézou systolicko-diastolického šelestu v prekordiu. Pacient byl v roce 2000 vyšetřen na jiném pracovišti jícnovou echokardiografií a nález byl zhodnocen jako nevýznamný defekt septa komor v pars membranacea o velikosti $3 \mathrm{~mm}$. Pro zhoršení fyzické výkonnosti (NYHA II u aktivního sportovce) byl znovu vyšetřen a nález posouzen jako zkrat z výtokové části levé komory srdeční do pravé síně. $\mathrm{Na}$ našem pracovišti bylo nutné provést nové vyšetření pomocí jícnové echokardiografie, které jasně dokumentovalo rupturu aneurysmatu nekoronárního Valsalvova sinu vyklenujícího se do pravé síně. Dopplerovsky byla ověřena komunikace mezi aneurysmatem a pravou síní. Aortální chlopeň byla bez stenózy s lehkou aortální insuficiencí

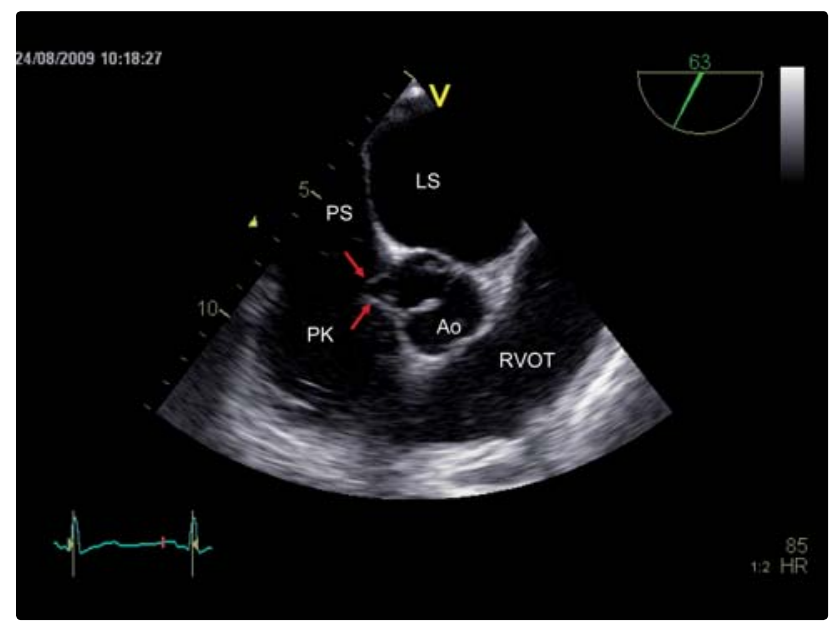

Obrázek 1 Jícnová echokardiografie - horní transezofageální projekce na bazi srdeční s rupturou stěny Valsalvova sinu

(Ao - aorta, PS - pravá síň, PK - pravá komora, RVOT - výtokový trakt pravé komory, LS - levá síň, červené šipky - stěna Valsalvova sinu s rupturou, žluté šipky - zkratové proudění) a byla potvrzena normální velikost kořene i ascendentní aorty. V descendentní aortě bylo detekováno pandiastolické obracení krevního proudu. Pravá komora měla kvůli objemovému přetížení hraniční velikost s normální systolickou funkcí. Při angiografii bulbu aorty byl potvrzen echokardiografický nález a zobrazena komunikace mezi nekoronárním Valsalvovým sinem a pravou síní. Při pravostranné katetrizaci byla zjištěna středně těžká plicní hypertenze se středním tlakem $\mathrm{v}$ plicnici $33 \mathrm{~mm} \mathrm{Hg}$ (53/20 mm Hg). Průtok zkratem byl 3,98 1/min s výsledným levopravým zkratem 1,9: 1 (stanoveno oxymetricky s odhadovanou spotřebou kyslíku). Pacient byl indikován $\mathrm{k}$ chirurgickému řešení a byla mu provedena plastika defektu Valsalvova sinu spolu s plastikou (dekalcifikací) aortální chlopně. Pro peroperační nález stř̌edně významné až významné mitrální regurgitace byl výkon doplněn současně o anuloplastiku mitrální chlopně. Pooperační průběh byl bez komplikací. Kontrolní vyšetření ověřilo vymizení

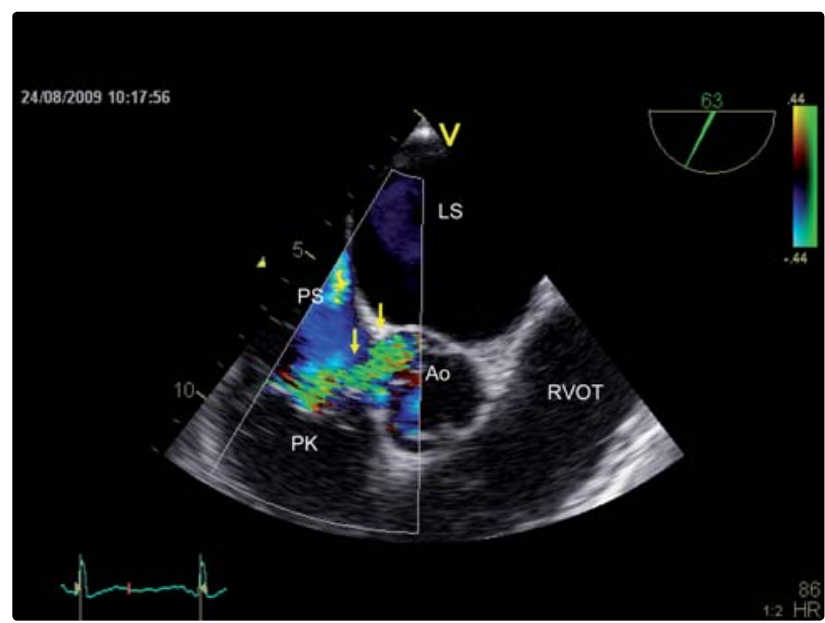

Obrázek 2 Jícnová echokardiografie - zobrazení zkratového jetu barevným dopplerovským vyšetřením 


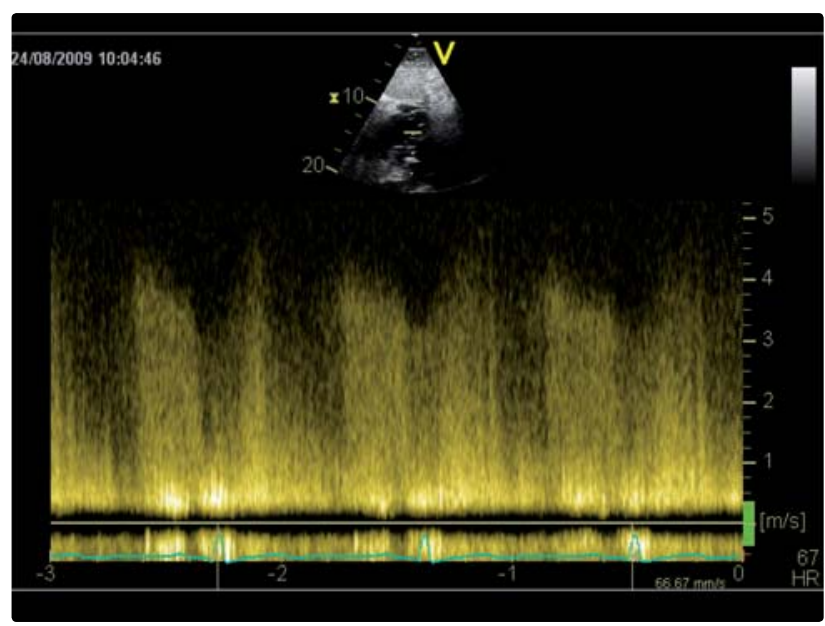

Obrázek 3 Kontinuální dopplerovský záznam zobrazující zkratové proudění rupturou Valsalvova sinu

levopravého zkratu a prokázalo pouze nevýznamnou mitrální regurgitaci.

Při vzniku aneurysmatu Valsalvova sinu se předpokládá vrozená méněcennost elastické komponenty medie nad anulem aortální chlopně. Tato vada bývá často sdružena s jinými vrozenými srdečními vadami. Nejčastěji bývá postižen pravý koronární sinus a méně často nekoronární Valsalvův sinus. Postupně dochází k dilataci aneurysmatu

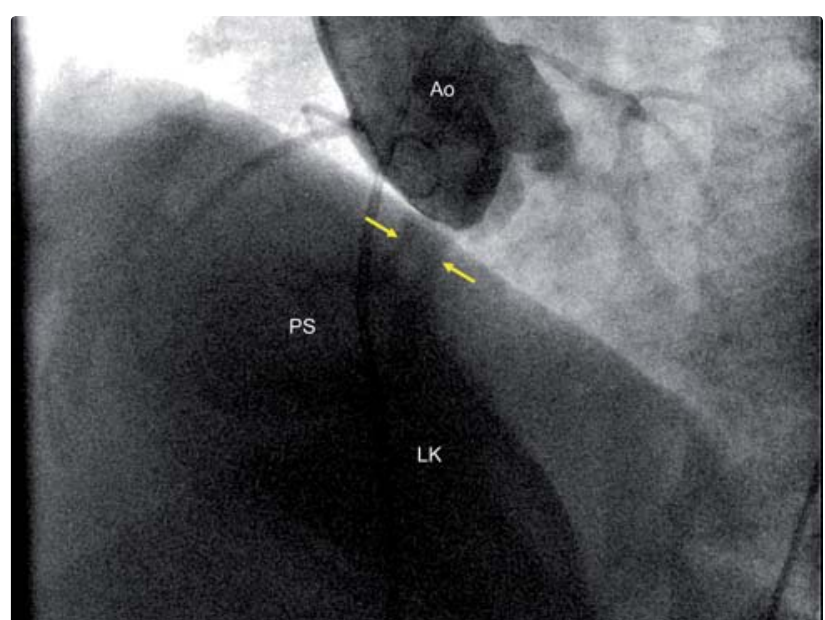

Obrázek 4 Angiografie bulbu aorty - levá šikmá projekce $s$ viditelným únikem kontrastu do pravé síně

a zvyšuje se riziko ruptury. $\mathrm{V}$ př́padě ruptury aneurysmatu se objevuje komunikace s pravou komorou nebo vzácněji s pravou síní. Výsledkem je různě významný levopravý zkrat. Symptomatologie závisí na velikosti zkratu a rychlosti progrese. Prvním klinickým př́znakem je obvykle námahová dušnost. Na vadu je možno vyslovit podezření podle přítomnosti kontinuálního šelestu, který bývá akcentován v diastole. Zobrazovací metodou volby je echokardiografie. 